\title{
PRECARITY, AGENCY, AND UNSUSTAINABILITY: THE MOBILITY OF YOUNG ADULT TOURISM WORKERS IN BANFF NATIONAL PARK, CANADA
}

\begin{abstract}
Angèle Smith
Abstract: This article focuses on young adults who travel to work and live in the Rocky Mountain resort destination of Banff National Park in western Canada. This is usually an early work experience in the lives of these young workers, often their first. I discuss the patterns and the impact of the work mobility of young adult tourism workers using three different frames of understanding: (a) the precarious employment associated with the tourism industry itself; (b) the specific place and community of Banff and how it shapes particular conditions of precarity and agency within the tourism industry and for young tourism workers' experiences; and (c) the young adult tourism workers themselves - their motives for work and travel, their experiences of work, and their agency in navigating the tourism industry in Banff. Using these three frames, I examine the impact of precarity and agency on the transfer of work knowledge, on the sustainability of the tourism industry work and the community, and on the young adult tourism workers' future work experiences. It is critical to examine work precarity, worker agency, and job and community sustainability in order to understand more fully the experiences of mobility of young adult tourism workers, and their early work experiences. This is all the more important as, in a climate of economic change and restructuring, young adult workers are becoming central to the consideration of employment policy issues.
\end{abstract}

Keywords: young adult, tourism worker, precarity, agency, community (un)sustainability, Banff

Angèle Smith PhD is Associate Professor and Chair of Anthropology, University of Northern British Columbia, 3333 University Way, Prince George, BC V2N $4 Z 9$.

Email: Angele.Smith@unbc.ca 
The Town of Banff, Alberta, lies within the bounds of Banff National Park in the Rocky Mountains of western Canada. A news headline in 2018 read: "Banff 'bursting at the seams'" (CTV News, 2018). In 2019, approximately 4.09 million people visited Banff National Park (Statista, 2020) - eclipsing the attendance figures of other parks across Canada. But the Park and town are a destination place not only for tourists, but also for the young adult tourism workers that supplement, and are indeed the backbone of, the tourism industry workforce. With a local population of just $9,658^{1}$ (Enns, 2018), it is not surprising that the tourism industry of the Town of Banff is dependent on the mobile young workers who come for a season or two to work in the national park and experience living there.

The tourism industry provides ample employment opportunities and is often a first-time or early work experience for young workers. At the height of Banff's two peak tourist seasons hiking in summer and skiing in winter - there is great demand for entry-level, cheaply paid workers. The young adults who fill these jobs are often backpackers or other travellers who simultaneously are tourism workers and semi-permanent residents in the community of Banff. However, in the shoulder seasons of fall and spring, there is a shortage of work relative to the number of young people looking for employment. For mobile young adult tourism workers, their work experience is often marked by instability and precarity: poor pay, shifting and part time work schedules, inability to get beyond entry-level jobs, challenging work conditions, and seasonality. In Banff specifically, they must also contend with living in an extremely expensive community with critical housing shortages. The result is that many of these young workers cannot find sustainable work and living conditions and must leave to find work elsewhere. Employers and workers alike are always in "training" mode as there is a cycle of workers leaving and new ones arriving. In other words, there is a cycle of precarity and unsustainability.

This paper draws on data collected for research undertaken through the On the Move

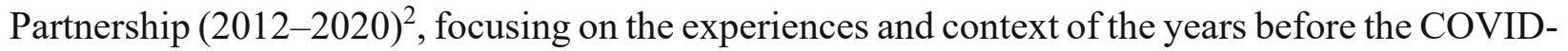
19 pandemic. I examine these first-time or early work experiences for young workers in the tourism industry in Banff National Park, with a primary focus on the Town of Banff, highlighting how these experiences are often marked by instability and precarity. It explores how large numbers of young workers must leave to find work elsewhere, meaning that there is little transfer of work knowledge and little attachment to place. At the same time, the study finds that many young

\footnotetext{
${ }^{1}$ According to the Banff 2017 Municipal Census Briefing (Enns, 2018), the permanent population was 8,865 and the shadow population was 793 for a total of 9,658. A shadow population is defined as "temporary residents of a municipality who are employed by an industrial or commercial establishment in the municipality for a minimum of 30 days within a municipal census year" (Alberta Municipal Affairs, 2018, p. 4). These are not considered "permanent" or usual residents.

${ }^{2}$ For more information about the "On the Move" Partnership research, see http://www.onthemovepartnership.ca/
} 
International Journal of Child, Youth and Family Studies (2021) 12(2): 65-87

workers gain valuable skills in negotiating the precarity of the work environment, having used their own agency and the flexibility of the work to develop their resilience and adaptability.

In this paper, I begin by contextualizing this study of young adult tourism workers in Banff National Park within the body of research carried out on employment-related geographic mobility and outline the research methods that I used to gather data. I discuss the patterns and the impact of the work mobility of these young adult tourism workers using three different frames of understanding. The first frame focuses on the precarious employment associated with the tourism industry itself. The second frame is concerned more specifically with the community of Banff and how it shapes particular conditions of precarity and agency within the tourism industry and for young tourism workers' experiences. This frame focuses on place-based conditions as well as the identity of the place of Banff National Park. The third frame focuses on the young adult tourism workers themselves - their motives for work and travel, their experiences of work, and their agency in navigating the tourism industry in Banff. I will use these three frames to examine the impact of precarity and agency on work knowledge, exploring what it means for the sustainability of the tourism industry and the community, as well as what it potentially means for the young adult tourism workers' future work experiences. Finally, I conclude with a discussion of how critical it is to examine work precarity, worker agency, and job and community sustainability in order to more fully understand the experiences of mobility and the early work experiences of young adult tourism workers.

\section{Research Context}

This research is part of a larger national (Canadian) "On the Move" project concerned with "employment related geographic mobility" and funded by a partnership grant from the Social Sciences and Humanities Research Council of Canada (2012-2020). The fundamental questions of this national study are concerned with why people move to a new community to find work, and what the impacts of that mobility pattern are for the workers, their work destinations, and the places and people left behind. My own research within this project deals specifically with the young adult mobile tourism workers coming to Banff National Park (primarily the Town of Banff and neighbouring Lake Louise) and explores their travel, work, and living experiences. The project investigates the key concepts of mobility, identity, and place through a longitudinal study and an in-depth ethnography of young adult tourism workers who have travelled to Banff to find work.

Banff is a "destination" tourist site, with many attractions that draw tourists from around the world, which results in tourism being the principal industry of the town and Park. It is an important research site for studying the community of tourism workers, but it also has symbolic and national importance. Banff is a Canadian icon with a long history. First Nations peoples lived on and visited these lands along the Bow River for more than 10,000 years (Langemann, 2011). The town of Banff in southern Alberta is located with the Treaty 7, signed in 1877 and encompassing the traditional territories of the Blackfoot Confederacy, the Tsuut'ina First Nations and the Stoney Nakoda Nations (Town of Banff, 2021a). Banff also is entwined with legends of Canadian nation- 
building in terms of exploring into the Western "wilderness" through the Rocky Mountains, and linking the nation from east to west with the construction of the Canadian Pacific Railway (Campbell, 2011). The heritage of Banff as Canada's first official National Park, as well as its UNESCO World Heritage designation, adds to this important image (Sainsbury, 2021). As a result, tourists, travellers, and would-be young tourism workers journey to Banff in large numbers. The distinctions between these different types of visitors often blur, adding yet another dimension to the particular characteristics of Banff that help to shape the experiences of those young people seeking employment at the start of their working lives.

\section{Method}

The research uses a mixed-method approach including both quantitative and qualitative techniques. My research team and I conducted participant observation in the Town of Banff on fieldwork trips (2011-2018); conducted one-on-one interviews and focus groups with residents, young adult workers, small tourism business operators, elected municipal officials, and staff and services workers of the Town of Banff; and carried out a household survey. We also surveyed newly arrived workers while they attended the Banff Heritage Ambassador program.

In carrying out participant observation, the research team recorded what they noticed, experienced, heard, saw, and talked about while in Banff. Information was recorded mostly in written journal notes, but also through photography and photojournalling. This method was a continual process used throughout the time in the field. Important primary data were collected through 40 one-on-one interviews over the various field seasons. The interviews provide a more in-depth perspective and understanding of living and working in Banff. Through the interviews, the research team gathered information on the participants' backgrounds, their travel and work expectations and experiences, their perceptions and knowledge of Banff housing and community, and their experiences and identity connected to Banff. The individuals interviewed included: young adult tourism workers, young adult migrant workers, social service providers (from BanffLIFE, Family and Community Support Services, Bow Valley Immigration Partnership, and Temporary Foreign Worker Support), business community members (hotel human resource managers and the director of the Banff Lake Louise Hotel Motel Association [BLLHMA]), community leaders (the Mayor and councillors), Banff Housing Corporation members, a Parks Canada human resource manager, local religious leaders, and residents.

In addition to these interviews, four focus groups were conducted with the aim of initiating a group discussion about the experiences of travelling, working, and living in Banff. These focus groups targeted mobile young adult workers; however, what was not anticipated, and proved very informative, was the diversity of the people who came to the focus group meetings. There was a wide range of participants in terms of age, length of time in Banff, and type of employment. Among the attendees, for example, were a middle-aged couple who had lived in Banff for more than 25 years, and a young tourism worker from Australia who had only arrived the day before the focus 
International Journal of Child, Youth and Family Studies (2021) 12(2): 65-87

group meeting. The result was a discussion that included many different viewpoints on living and working in Banff.

Finally, we conducted a household survey in specific residential areas known to have a higher population of young migrant workers, based on data from the Town of Banff Census (Pivotal Research, 2011). Participants were asked to complete the surveys for collection two to three days later. The surveys included questions concerning background information of the individual resident filling out the survey, including their length of time in Banff and reasons for coming, type of work, housing, and perceptions of the community. The household surveys provided another set of data and a means of identifying participants interested in follow-up one-on-one interviews or participation in a focus group.

\section{Discussion}

Using the research methods described above, I examined the data using the three frames of understanding to better interpret the patterns and impact of the work mobility of the young adult tourism workers in Banff. The first is concerned with the tourism industry itself and the prevalence of precarious employment within it.

\section{Tourism Industry Frame}

If work precarity is the lack of job predictability, protection, and security, characterized by poor pay (Standing, 2016), then it is not surprising that tourism work is inherently precarious. This kind of work thus shapes the work mobility patterns of young adult tourism workers, placing sometimes intolerable demands on the flexibility of workers, to the point that many feel compelled to leave in search of more secure job situations. Lee et al. (2015) argued that "work in the tourism industry is increasingly precarious in the descriptive sense [of being] ... uncertain, contingent and exploitative" (p. 217).

This description of precarious work accurately describes the tourism industry in Banff and young adult tourism workers' experiences of working and living in the Banff area. Tourism's key subindustries and services in Banff (as noted in Figure 1) include accommodation, food and beverage services, transportation, guiding/ski area services (as examples of recreation and entertainment, and travel services), and retail sales and service (Pivotal Research, 2011). There is a wide variety of jobs within these subindustries and services. For example, the food and beverage kitchen category employs cooks, kitchen helpers, dishwashers, and cleaners; food and beverage front lines include restaurant servers, hosts, bus persons, baristas, bartenders, and delivery drivers; hotels need workers in housekeeping and cleaning, hotel guest services, and office and administration; in the transportation sector, there are bus, van, and taxi drivers; local stores employ retail and customer service staff; and entertainment and travel services require tourist guides and operators, ski instructors, ski lift and customer service staff, and river guides. 
Figure 1. Banff Employment in Tourism Sector

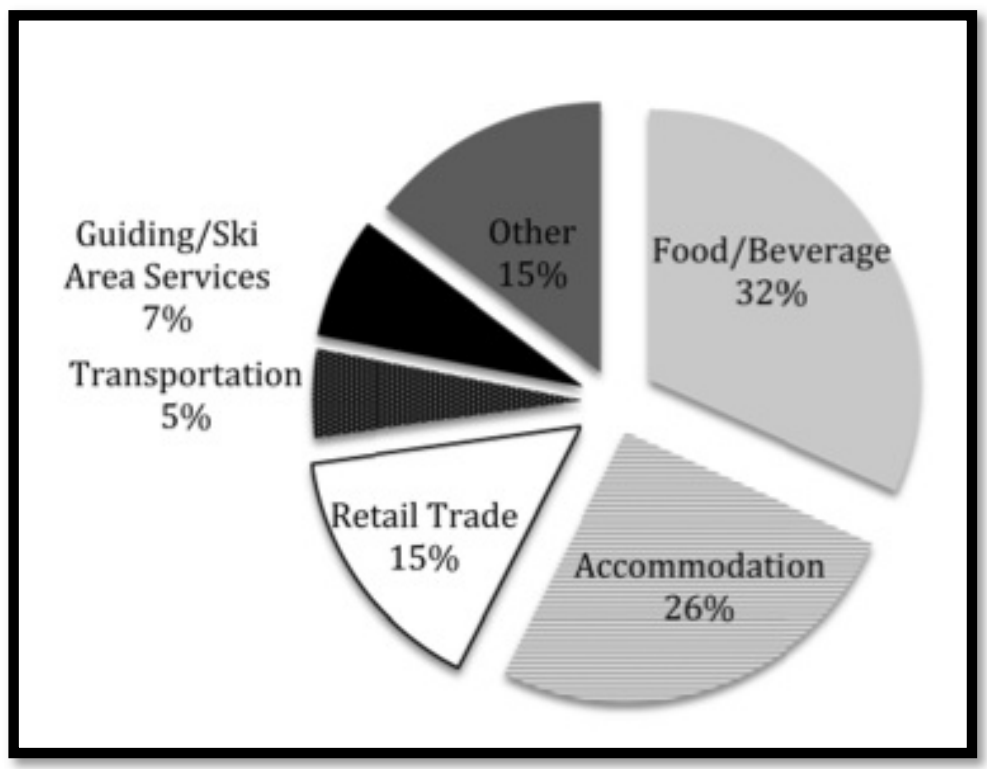

Note. Adapted from the Town of Banff Municipal Census, 2011, (p. 20), conducted by Pivotal Research Ltd.

The pattern of these subindustries and services that provide tourism jobs in Banff is comparable to the distribution of such jobs nationally, where food and beverage work combined with accommodation work make up the largest number of jobs $\left(51 \%\right.$; see Figure $\left.2^{3}\right)$.

Figure 2. Job Breakdown Within Tourism Industry Nation-Wide

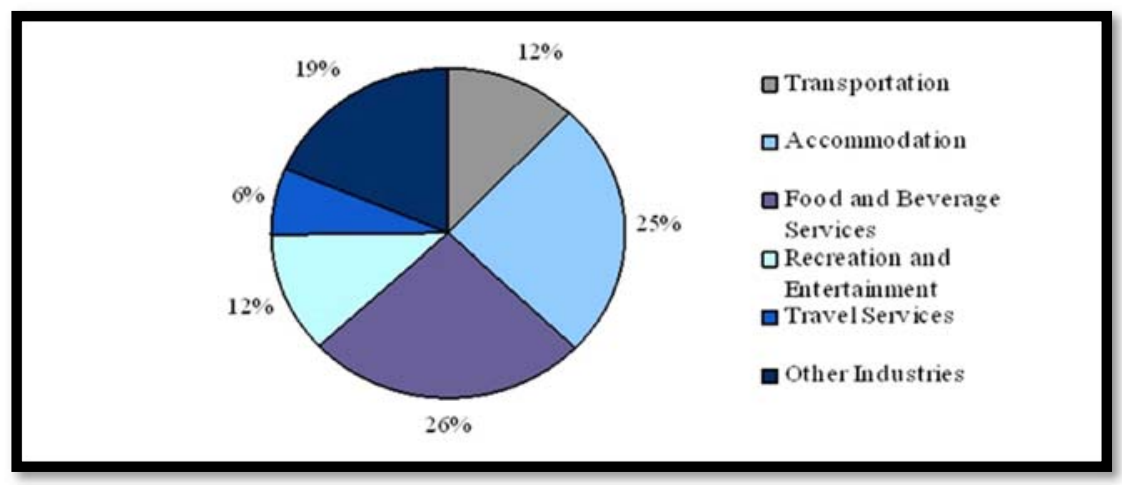

Note. The figure uses data averaged over four quarters from Statistics Canada, 2013, Employment generated by tourism (x 1,000) [CANSIM Table 387-0003]. doi:10.25318/3610023201-eng

\footnotetext{
${ }^{3}$ I am using the data from Bow Valley Labour Market Reviews (LMRs) of August 2018 to January 2019 (The Job Resource Centre, 2019a), and February to July 2019 (The Job Resource Centre, 2019b). More recent LMRs do not show typical patterns as a result of the impacts of COVID-19 on the tourism industry in the Banff area.
} 
These subindustries and services tourism jobs make up a large proportion of the occupational demands in Banff as recorded in the Bow Valley ${ }^{4}$ Job Resource Centre report (2019b) for the period of February to July 2019 (see Figure 3).

Figure 3. February to July 2019 Occupational Demand

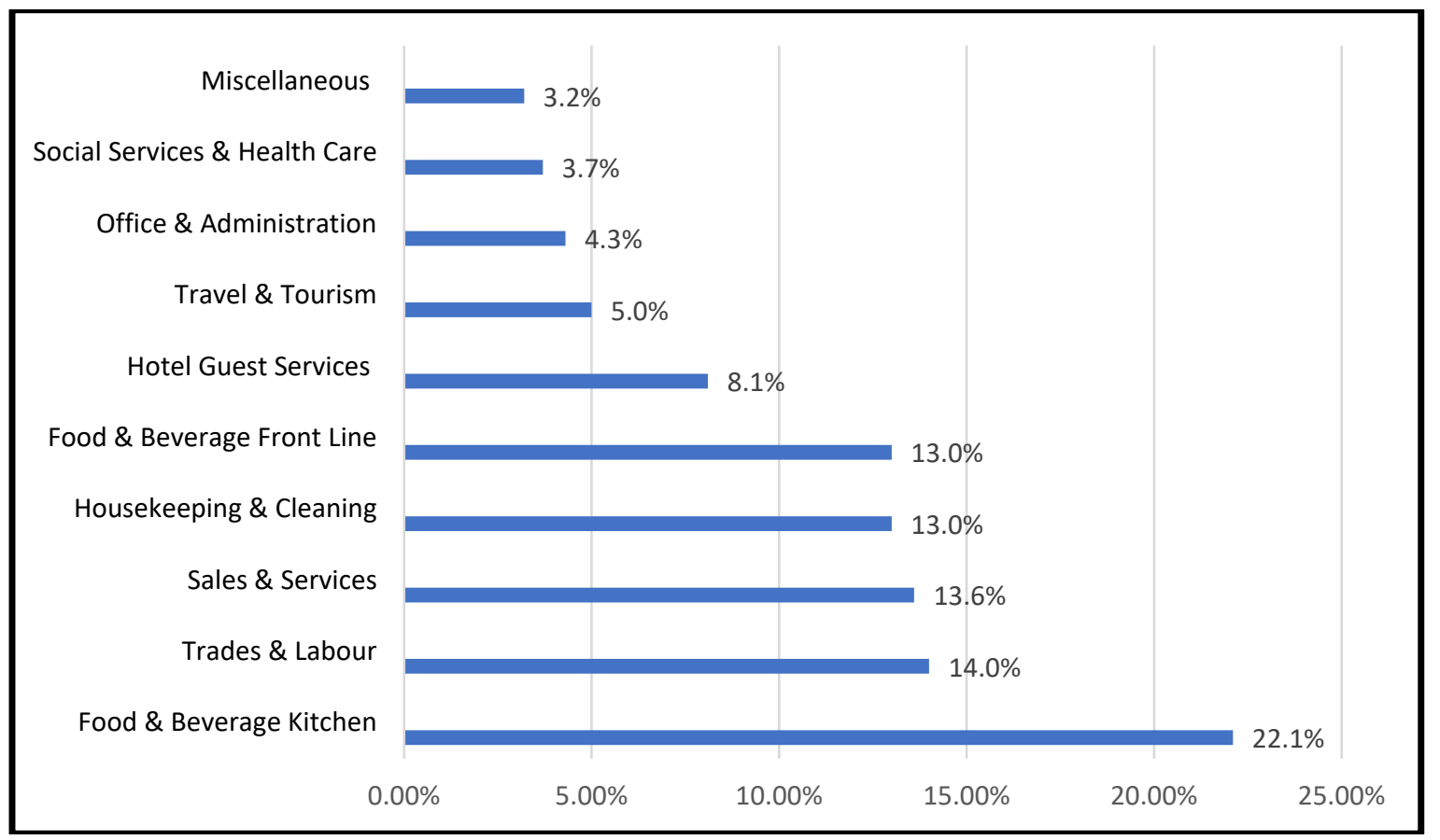

Note. The figure is adapted from The Job Resource Centre (2019b), Bow Valley Labour Market Review: Fall 2019, p. 2.

Tourism work in Banff consists almost exclusively of entry-level jobs with little opportunity for advancement. Additionally, many of these jobs are part-time. Nationally, the ratio of full-time to part-time work is about 4 to $1(80.7 \%$ vs. $19.3 \%$; Statistics Canada, 2015); in Banff that ratio is just 3 to 2 (60\% vs. 40\%; Deloitte LLP, 2014). Entry-level and part-time jobs offer limited potential for young adult tourism workers to make a sustainable living.

Further, the wages paid to these workers are consistently low, especially given the region's cost of living (as will be discussed below). A minimum wage of $\$ 15$ per hour has been in effect in Alberta since October 2018 (Retail Council of Canada, 2021). For the spring of 2019, the local Bow Valley Job Resource Centre (2019a) reported that the lowest average wages were for frontline food and beverage work at an hourly rate of $\$ 15.63$ before gratuities; followed by the accommodation sector at $\$ 16.38$ for housekeeping and cleaning and $\$ 16.57$ for hotel guest services; $\$ 16.72$ for retail sales and services; $\$ 17.62$ for food and beverage preparation and dishwashing; and \$18.94 for travel and tourism (park interpreters, guides, tour operators and bus,

\footnotetext{
${ }^{4}$ The Bow Valley is the local area along the Bow River and includes the town of Banff and hamlet of Lake Louise in addition to other small communities.
} 
van, and taxi drivers). These wages are above the minimum wage set for the province of Alberta; however, the cost of living and housing in Banff means that workers still struggle to make ends meet, as will be discussed below.

While food and beverage servers are often able to supplement their wages with gratuities, the same cannot be said of other job categories. Some workers might benefit marginally if, for example, there is centralized tipping amongst the housekeeping staff at a hotel, but as one worker explained in an interview, this amounted to only an extra $\$ 36$ per month. Low wages are a chronic issue that is exacerbated by shorter shifts ( 5 hours instead of 8 ) and fewer shifts per week as the peak season draws to an end. Tourism workers are often not given fixed hours or a regular schedule, making it logistically difficult for them to accommodate a second job as they are never sure of their work schedule from week to week. Even so, many, if not most, of the young adult workers interviewed explained that they had to work multiple jobs in order to manage financially while living in Banff. As one of the small tourism operators explained:

You might be sold on the idea that you can come to Banff to work in a coffee shop and go hiking every weekend, but then by the time you have paid for your accommodation and the food on your table, you realize that you are working 60 hours a week just to do that and you have no time to go hiking or skiing; a lot of people come here planning to work one job but end up with two just to make ends meet. (Small Tourism Operator Interview C, February 17, 2012)

For young adult tourism workers, the industry provides little or no job security. In part this reflects uncertainties typical of the tourist market, which is affected by many external variables, such as weather, natural disasters, or changes in economic conditions or political climate (Lee et al., 2015) such as resulted in 2020 to 2021 from the COVID-19 pandemic (Macfarlane, 2020). In Banff, specifically, the work is seasonal, with peak seasons in winter and summer, and "shoulder" seasons in fall and spring. Figures 4 and 5 illustrate the job supply and demand during two periods, August 2018 to January 2019, and February to July 20195. These graphs clearly show the high and low seasons of employment. In the Fall/Winter graph (Figure 4), the Job Centre in Banff reported that during this period, the Centre "served 13,470 job seekers and posted 1,511 jobs", suggesting that those seeking jobs had a success rate of only 11.2\%. In the Spring/Summer graph (Figure 5), the Centre "served 11,123 job seekers and posted 2,240 jobs", suggesting a success rate of 20.1\%. While the success rate during the summer peak season is significantly higher than that in the winter peak season, these low numbers indicate that, in general, finding work can be challenging in this tourism destination.

\footnotetext{
${ }^{5}$ Again, I am using pre-COVID-19 data as a better example of tourism work for young adults in more typical years.
} 
Figure 4. August 2018 to January 2019 Job Supply and Demand in Banff

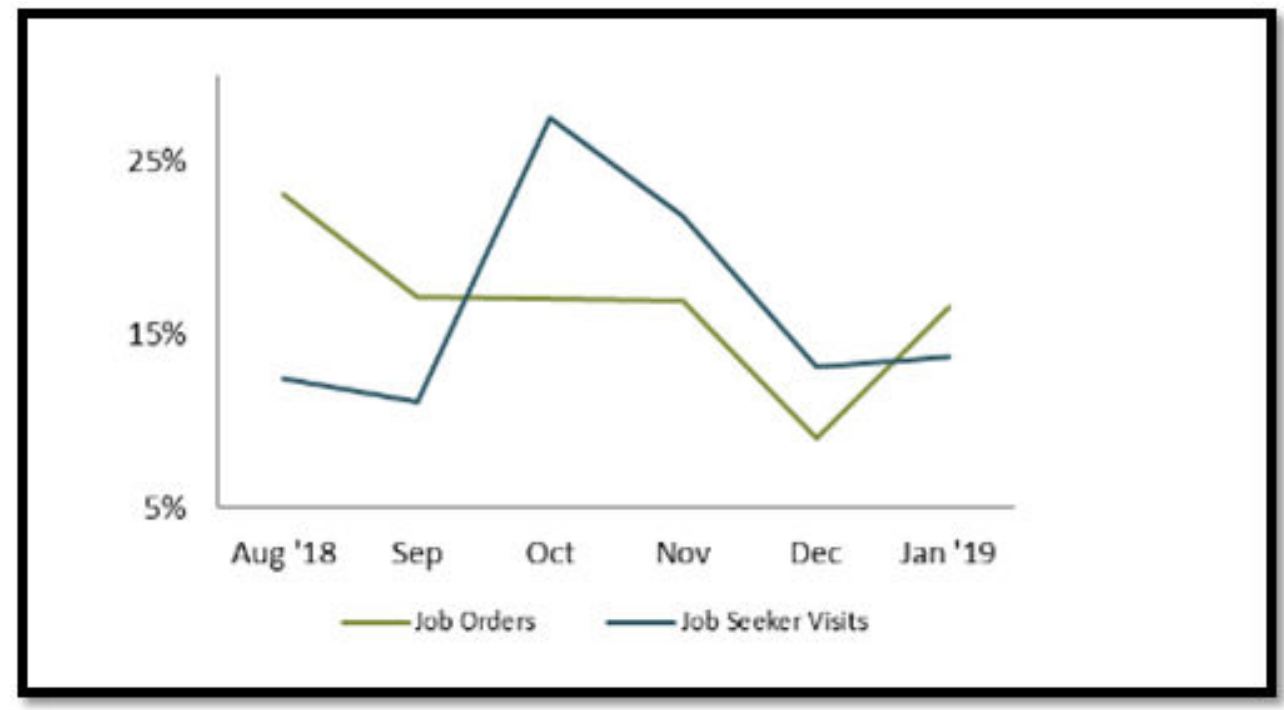

Note. The figure is from The Job Resource Centre (2019a), Bow Valley Labour Market Review: Spring 2019, p. 2.

Figure 5. February to July 2019 Job Supply and Demand in Banff

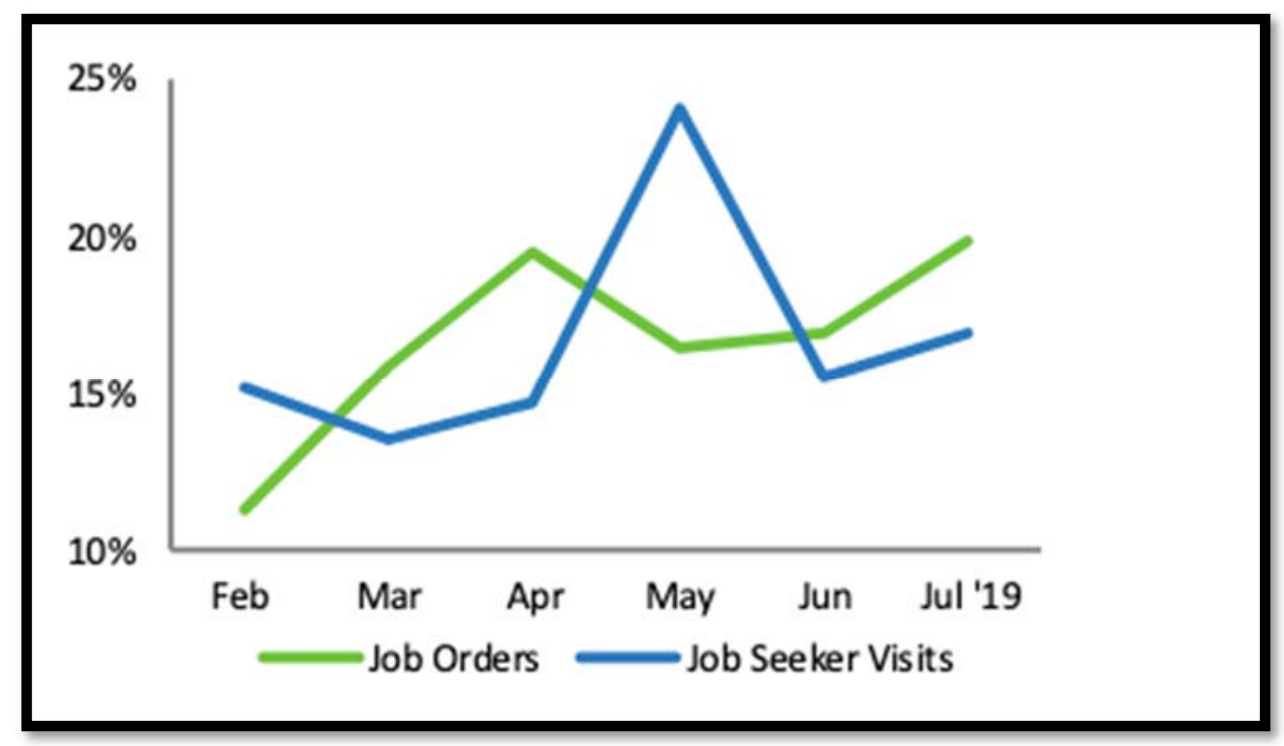

Note. The figure is from The Job Resource Centre (2019b), Bow Valley Labour Market Review: Fall 2019, p. 2.

There is no real chance for a tourism worker to move "up the ladder" and thus few prospects for job permanency or any prospect of putting down roots in the community. In other words, the employment constraints of the tourism industry mean that workers are treated as "disposable" (Smith, 2018b). The expectation that workers are non-permanent - that they will move on from Banff - and thus subject to precarity, is intrinsic to the tourism industry. Thus employers and workers are always in "training" mode as the cycle of workers leaving and new ones arriving continues. There is little transfer of work knowledge, and little attachment to place. And in a place 
International Journal of Child, Youth and Family Studies (2021) 12(2): 65-87

like the Banff community, there are additional challenges shaping the work mobility patterns of young workers. This leads us to the second frame.

\section{The Community of Banff Frame}

The infrastructure of the place and community of Banff also influences the work mobility patterns, making it challenging for the young tourism workers to stay for any length of time. These factors contribute to the precarity of their experiences working and living in this tourism destination place, and create a work and community environment based on unsustainability.

As with many tourist destinations, housing costs in the Town of Banff are exorbitantly high and vacancy rates are extremely low. After several years of $0 \%$ vacancy rate, the town's ongoing housing crunch relaxed slightly in 2019 when the residential vacancy rate was reported to be $1.1 \%$ (Town of Banff Information, 2019). While the Banff Community Housing strategy identified a healthy vacancy rate as between $3 \%$ and $5 \%$, the Mayor, Karen Sorensen, commented that, "This is a positive step in the right direction" (Ellis, 2019). Comparatively, the overall provincial vacancy rate across Alberta increased from 11.7\% in 2017 to $13.3 \%$ in 2018 . Further, "according to the provincial survey, the highest end of the rental ranges across Alberta was in Banff: two-bedroom units at $\$ 3,600$ and four-plus bedroom unit[s] at $\$ 4,000$. Average provincial rates for two-bedroom were $\$ 893$ and for four-bedroom \$1,436" (Ellis, 2019). These rental rates illustrate the prohibitively high housing costs confronting young adult tourism workers (see Figure 6 for rental costs in Banff and Canmore).

Figure 6. Rental Costs per Month in Banff and Canmore

\begin{tabular}{|c|c|c|}
\hline $\begin{array}{l}\text { AVERAGE } \\
\text { RENTAL RATES* }\end{array}$ & BANFF & CANMORE \\
\hline 1 Bedroom & $\$ 1,528$ & $\$ 1,422$ \\
\hline 2 Bedroom & $\$ 1,995$ & $\$ 1,767$ \\
\hline 3 Bedroom & $\$ 2,500$ & $\$ 2,250$ \\
\hline Studio/Bachelor & $\$ 1,104$ & $\$ 946$ \\
\hline Roommate/Shared & $\$ 859$ & $\$ 856$ \\
\hline Total Listings & 286 & 591 \\
\hline
\end{tabular}

Note. The figure is from The Job Resource Centre (2019a), Bow Valley Labour Market Review: Spring 2019, p. 3.

As a result of the high prices, rental accommodations in Banff are often overcrowded, sometimes illegally so; it is not unusual to have 6 or more young adults living in one apartment (field notes, 2012). Speaking at a housing forum put on by the Banff Housing Corporation that was attended during the 2013 field season, several young tourism workers explained that they had 
practised illegal squatting, couch-surfing with friends, or "sleeping on the floor behind the couch" in an overcrowded apartment (field notes, 2013). In an interview, one official explained that it is a "landlords' market" and that many take advantage of the situation (Interview C, February 16, 2012). Town officials are aware of the cramped conditions, but withhold enforcement of laws prohibiting them rather than leave many young adult tourism workers without accommodation.

Some types of work (e.g., in hotels, motels, and hostels) provide staff accommodations, often located on the same premises as the work itself (field notes, 2013). But this situation has its own issues. Although rents under these arrangements are often comparatively low, they must still be paid from the worker's low wages, which are thus effectively siphoned back into the pockets of the employer. The worker accommodations are often run down and crowded. Workers share bedrooms and, in some circumstances, share a communal kitchen, living room, and dining room with as many as 30 people. Workers reported being afraid to complain about these conditions because their landlords are also their employers. If they were turned out of staff accommodation, they would face the same difficulties as others in finding affordable housing in town. In staff accommodations, there is little divide between work and "home life" and "You can't get away from either your boss or your co-workers", as one hotel worker complained.

Another result of the high costs and low vacancy rates is that the neighbouring town of Canmore, just $25 \mathrm{~km}$ away but outside of Banff National Park, has become a bedroom community for the Town of Banff. While the residential vacancy rate in Canmore is a healthy 5\% (Alberta Regional Dashboard, 2019), the housing is also very expensive; as in the Town of Banff, this has led to overcrowding of shared accommodations. One tour operator working in Banff explained that he had been living in Calgary (130 km from Banff) because the housing was cheaper, but, "After working a 9-hour day whitewater rafting and then having a 3-hour commute on top of that to and from Calgary every day - it really wears on you - and I moved to Canmore" (Interview A, February 17, 2012).

To get a sense of what those housing costs really mean, we can recall the average wages of some of these young adult tourism workers. Assuming a 35-hour work week, a front line food and beverage server making $\$ 15.63$ per hour would make $\$ 2,188$ a month before taxes $(\$ 26,256$ a year). A housekeeping cleaner at $\$ 16.38$ per hour would make $\$ 2,293$ a month before taxes ( $\$ 27,516$ a year). It a general rule that the cost of accommodation should not be more than $30 \%$ of take-home pay (Broverman, 2021). However, when comparing these monthly salaries to the rental costs in Banff of cheaper types of accommodation (1-bedroom, studio/bachelor, or shared; see Figure 6), the server would be spending more than $69.8 \%, 50.5 \%$, or $39.2 \%$ of her or his monthly salary, respectively, while the housekeeping cleaner would be spending more than $66.6 \%, 48.1 \%$, or $37.5 \%$ of her or his salary.

Beyond its high housing costs and low residential vacancy rates, the Town of Banff is in some ways unique, as it is a "town within a park". That is, as a municipality within a national park, the Town of Banff is in the distinct position of being governed equally by its elected municipal council 
and by the federal Canada National Parks $\mathrm{Act}^{6}$, which attempts to maintain a balance between the needs of the town and the ecological integrity of the national park. It does this by legislating that the town cannot grow beyond specific boundaries (either horizontally or vertically) and by a policy objective that caps the town population at 8,000 residents. This objective is realized in a "need to reside" policy mandating that one must be employed in Banff in order to reside legally in the town (Town of Banff, 2021b). As a result, many who come to the Town of Banff looking for work, or are between jobs there, are in violation of this law.

The Town of Banff's community plan suggests the number of permanent residents should be fewer than 10,000, even though this exceeds the Canada National Parks Act mandate of a population of 8,000 (Ellis, 2013). In 2017, the town population was 9,658 (Enns, 2018). Therefore, the population size has reached a critical point as evidenced by the housing crisis, which is an issue of concern for both park and town. The policies that manage the community's imperative to "remain small" have a direct impact on the work and living experiences of everyone in the Town of Banff, especially the young adult tourism workers.

Finally, the co-governance arrangement between the Town Council and Parks Canada at the federal level results in a friction between the growth objective of the town and its tourism economy, and Park Canada's objective of environmental and community sustainability. This conflict between rival objectives is not unique to Banff. In the last 5 years, there has been increasing concern with "overtourism", which the United Nations World Tourism Organization (UNWTO) defines as "the impact of tourism on a destination, or parts thereof, that excessively influences perceived quality of life of citizens and/or quality of visitor experiences in a negative way" (UNWTO et al., 2018, pg. 4). As well as threatening community sustainability, overtourism also threatens the natural environment that is the basis of, and attraction for, tourism (Smith, 2018a). According to the UNWTO, a three-pillar approach to sustainability - economic, environmental, and sociocultural - has been incorporated into tourism destination agendas globally (UNWTO, n.d.); however, as Mihalic (2020) argued: "In reality, tourism destinations continue to encourage economic growth [and]... are strongly embedded in a capitalistic socio-political system" (p. 1). This is very much the case in the Town of Banff, and young tourism workers are often caught in the middle of this tension.

Tourism is almost the sole economy of the Park and the Town of Banff, which attract more than four million visitors each year (roughly 400 times the resident population). Because of the constraints on the population of the town through the Canada National Parks Act, non-local and temporary tourism workers are essential to maintaining this economy. But as tourism grows, the number of young tourism workers grows, and their residence in Banff can be viewed as a violation of the population restrictions in the Town of Banff, signifying overtourism and threatening community and environmental sustainability.

\footnotetext{
${ }^{6}$ https://laws-lois.justice.gc.ca/eng/acts/n-14.01/
} 
Moreover, young tourism workers in the Town of Banff are caught in the middle of the tension between tourism growth and community sustainability because of the difficulties of making a living with the precariousness of tourism work and the challenges to finding accommodation in Banff. The tourism workers are often simultaneously backpackers or travellers, as well as tourism workers and (semi-permanent) residents. Even if they do want to remain in Banff and make a life for themselves, most are not able to stay due to the low wages and lack of prospects of advancement, coupled with the high cost of living and lack of affordable housing. These structural impediments are built-in mechanisms that help to maintain the mandate of a small-town population, but they also raise concerns about community sustainability.

Municipal officials have stated in interviews (Interviews M \& N, August 27, 2016) that it is impossible to know the exact number of mobile young adult tourism workers actually working and living in Banff. This is partly due to the housing issue, and the substandard and sometimes illegal accommodations available to these temporary workers. The 2011 Town of Banff municipal census (Pivotal Research, 2011) counted about a thousand "temporary" workers $(12.5 \%$ of the population $)^{7}$. Many of these individuals would certainly have been mobile tourism workers. However, it likely that their actual numbers were considerably higher, as the census often misses people who are living more marginally: those who are mobile or who have irregular housing arrangements largely go uncounted.

The temporary and fluid nature of the town population is evident in data from 2011 showing that that more than $60 \%$ of Banff residents had lived there for less than 10 years (Pivotal Research, 2011). Of residents who had lived in the community for less than 5 years, nearly half were newcomers to either Canada (26.5\%) or the province (22.4\%; Pivotal Research, 2011). This indicates a highly mobile and fluid population. What is more, the population is relatively youthful, with $44 \%$ of the population between the ages of 15 and 34 (Pivotal Research, 2011). These demographics reinforce the presence of a young adult mobile tourism workforce, which is the focus of the third frame.

\section{The Young Adult Tourism Workers Frame}

Consideration must be given to the agency, choice-making, and particular circumstances of young adult tourism workers. Two main characteristics of these workers are that first, by necessity, they are non-local - "from away"; and second, this is often one of their first work experiences. Many have no expectation that their work in Banff will be long-lasting or permanent.

Commenting on the fact that young adult tourism workers come from elsewhere in Canada and from international locations, Darren Reeder, executive director of BLLHMA, said: "We have no ability to recruit in our backyards. Being in a national park, where things are expensive and housing is expensive, it just makes this an incredibly difficult place to attract people and to keep them longterm" (D'Aliesio, 2014, para. 21). The difficulty of attracting Canadians to live and work in Banff

\footnotetext{
${ }^{7}$ This detailed information is not publicly available for the 2014 and 2017 municipal census reports.
} 
is confirmed in interviews with numerous hotel human resource managers who stated that, in their experience, young adult Canadians did not want to work for the low wages paid in the temporary entry-level tourism jobs offered in Banff despite the appeal of the mountain location and lifestyle (Hotel Manager Interviews G, H, I, \& J, August 20-24, 2016).

The BLLHMA (2014) "Destination Labour Attraction and Retention Strategy" report commented on immigration and ethnocultural diversity in Banff, noting: "Banff's population has always included a strong immigrant component" (p. 6). Further, the town's immigrant population has grown substantially (Municipal Official Interviews M \& N, August 27, 2016). According to the BLLHMA, the majority of these new immigrants came from the Philippines and from Japan. Prior to COVID-19, these immigration numbers reflected the increase in the total number of temporary foreign workers (TFWs; Employment and Social Development Canada, n.d.) ${ }^{8}$ and young adults on International Experience Canada (IEC) programs (Immigration and Citizenship Canada, n.d.).

The IEC initiative is a program administered by Immigration and Citizenship Canada (n.d.) that provides young individuals between the ages of 18 and 35 the opportunity to travel to and work in Canada. It is these mobile young adults, not the TFWs, that are the real focus of my analysis, as "IEC employed workers are more numerous in Banff \& Lake Louise tourism businesses than hires from the regular TFW stream" (Tourism Industry Association Canada \& Banff and Lake Louise Hospitality Association, 2014, p. 12). The IEC program is available in 33 countries, including the United States, Australia, New Zealand, Britain, Germany, Japan, Korea, and the Czech Republic. The IEC program offers travel authorization and temporary work permits for one or two years depending on the country of origin and young adult workers can choose from three different travel and work experiences, including: Working Holiday, Young Professionals or International Co-op Internship. Work permits are Labour Market Impact Assessmentexempt (LMIA) and are either employer-specific (Young Professionals and International Co-op) or open work permits (Working Holiday). Young adults on the IEC program who become tourism workers in Banff often are backpackers, students, or on gap year vacations, looking for seasonal or temporary work. In the past, the IEC has been based on an "invitation-to-apply" model, in which an employer must invite a participant to apply for the IEC, but under COVID-19 in 2021, a potential worker must furnish proof of a valid job offer in order to receive an invitation to apply for the 2021 season (Immigration and Citizenship Canada, n.d.).

The second characteristic of the young tourism workers in Banff is that this is often an early work experience for them, and one that is commonly fraught with challenging economic circumstances. As one tourism worker, a young woman, explained in an interview (Interview A, February 17, 2012), she had been offered a job in the day care centre at one of the local ski hills.

\footnotetext{
${ }^{8}$ The government's goal to get Albertans back to work during and after COVID-19 has impacted Banff as frontline tourism occupations were added to the "refusal to process list", meaning a drop in the number of new TFWs in the Banff tourism industry (Ellis, 2020).
} 
Her pay before taxes would have been $\$ 8$ per hour. She calculated that after paying her own mileage and gas to get to and from the ski hill every day, her take-home salary would not pay for her rent and would barely keep her fed. She explained, "People are working full-time in gift shops but don't have enough money to put food on the table - they are having to get food baskets to just eat in Banff" (Tourism Worker Interview A, February 17, 2012). She did not expect to stay on for another season of work.

Another young woman in the Housing Forum focus group (February 20, 2013) recounted that she had been working in Toronto but had come to Banff for the lifestyle. She liked the idea of balancing work and play while living in the backyard of a National Park, but also had deliberate plans to work her way up in the tourism industry in Banff. In Toronto, she had paid a lot for rent but was still able to save. However, when she arrived in Banff and found work, her job on the front desk of a hotel earned only half what she had received in Toronto, while the rent on her studio apartment was only marginally less than she had been paying there. As a result, she was not able to save money, nor was she able to "play" in and appreciate the scenic location because she was scheduled for so many shifts (Housing Forum focus group, February 20, 2013). She worried that if she stayed in Banff, she would not be able to realize her career goals.

Others expressed contrasting views. In a Tourism Worker focus group, one young woman in her mid-20s said, "I think Banff is good because it's easy to get jobs. Most of the time you have options" (Tourism Worker Focus Session 1, July 25, 2013). Pierre (a pseudonym) also recounted how easy it had been for him to find work:

I arrived here and within a week I found a job that had staff accommodation. And I'm like, "Wow, this is pretty sweet" ... even though I have to share one room with two other people. But, I mean, you're still in that vacation mode. So that was for the summertime, and I even met a girl. So, I'm like, "Wow, it's easy here." And that's the thing: it is easy in Banff. Find a job? Within a week, you got a job. (Tourism Worker Focus Session 2, July 25, 2013)

However, as these are low-paying, entry-level jobs, with no benefits and little job security, it is not likely that these young workers will be able to maintain these jobs and their life in Banff, especially through the shoulder season when fewer jobs are available. Samantha (a pseudonym) explained:

When I moved here, because I have a university degree, I had a career back home, so I was expecting to find the same thing here. And I'm not. I'm not able to get a real job.... After seven years, I'm not able to get that real job. I'm still doing those entry-level positions that basically anyone can do... And, of course, one issue that we have in Banff is the cost of living. It is almost impossible to say, "Hey, I'm going to find a place of my own to live in." Even if I had a good job, it's so 
International Journal of Child, Youth and Family Studies (2021) 12(2): 65-87

expensive to have your own place. That's why, after seven years, maybe it's time to move on. (Tourism Worker Interview E, August 4, 2014)

While some of these young adults came to Banff expecting to live a balanced life of work and play, enjoying hiking and skiing in the National Park, or having an "iconic Canadian experience" (Interview A, February 17, 2012), the reality is quite different. The working and living conditions in Banff's tourism industry keep young adult workers in a marginal economic and social position, often and ultimately forcing most of them to move on.

\section{Impacts of Tourism Worker Precarity and Agency}

The three frames (tourism industry, Banff community, and the young adult tourism workers) clearly demonstrate what these experiences of precarity and marginal economic and social standing mean for young adult workers. It is also important to recognize the impact this precarity has on the employers and the tourism industry, as well as the sustainability of the town itself. Another aspect to examine is the different objectives that the young adult tourism workers may have - what they expect from, and what they get out of, their work experiences in Banff — and to understand the agency and motivations of the young adult workers themselves.

What is the Impact of Precarity on the Employers, the Tourism Industry, and the Town Itself?

Tourism industry work in Banff is based almost exclusively on entry-level jobs that pay low wages, offering no benefits and little job security. At the height of the tourist seasons in winter and summer, jobs are plentiful and employees can move from job to job with relative ease. Because the supply of labour in the form of these mobile workers is ample, their remuneration is low: minimum wage, perhaps augmented with a free ski pass or similar bonus, is the norm. However, when the tourist boom slows during the shoulder seasons in the spring and fall, many employees are let go. The high cost of living means that these unemployed young adults cannot then afford to continue to live in Banff, so they either elect to leave or have no choice but to do so. Thus, the economy is dependent on low-paying entry-level positions that can be filled with a seemingly endless supply of new labour: a new crop of mobile workers will be hired when the next peak season comes.

Employers claimed that their businesses would not survive unless wages continued to be kept low (Hotel Manager Interviews G, H, I, \& J, August 20, 2016). One young adult worker interviewee complained that, "Employers take advantage of workers, especially those that are here on work visas, then the employers basically own you" (Tourism Worker Interview E, August 4, 2014), a view that was shared by others. The one decisive option that the young adult mobile worker could exercise was to leave. This defines both tourism worker agency and the ambiguity in the young adult workers' identity: "essential" for the survival of the tourism industry, yet "disposable" because the next season will bring a new supply of workers willing to accept these circumstances. Workers are expected, if not encouraged, to "move on": the tourism industry, in fact, depends on the continued work precarity of its employees. 
As a result, the transfer of work knowledge from experienced worker to novice, which occurs in many other work settings, was impaired or did not take place at all among these highly mobile young tourism workers. Williams (2012) discussed the impact that tourism workers' mobility has on the human capital of knowledge and skills. He identified three types of skills that are affected: technical skills (involving high levels of practical work); routine skills (including repetitive work); and social skills (which facilitate communication and social interaction). The detachment of skills and the potential for low productivity, along with the labour flows in Banff, affected the experiences of the workers in training as well as the level of tourism services the area could provide.

The experiences of young tourism workers in Banff will ultimately be determined by the sustainability of the tourism industry there. The study of sustainability derives from ecology and centres on the idea of living within the carrying capacity of the supporting ecosystem. When approached more broadly, "The concept of sustainability holds that the social, economic and environmental factors within human communities must be viewed interactively and systematically" (Maida, 2011, pg. 1; see also Munasinghe, 2007; and in relation specifically to tourism, Mihalic, 2020; UNWTO, n.d.; Wall, 2019, 2020). According to The Brundtland Report (World Commission on Environment and Development, 1987), community sustainability must meet "the needs of the present without compromising the ability of future generations to meet their own needs" (p. 8).

This idea suggests that a community can only be healthy or sustainable by maintaining its holistic self — by simultaneously upholding its environmental, economic, and social sustainability. The issues of this kind of integrated sustainability were at the root of the assessment reports produced by the Town of Banff and the BLLHMA. These include: The Town of Banff Community Social Assessment (Family and Community Support Services, 2014; Gerrits et al., 2019); The Town of Banff Economic Prosperity Strategy (Deloitte LLP, 2014; Meier, 2013); The Town of Banff Housing Strategy (Community Housing Strategy Committee, 2014); and the Banff Lake Louise Destination Labour Attraction and Retention Strategy (BLLHMA, 2014). Because of the unique position of the Town of Banff, much care has been taken through federal and municipal policy to sustain the ecological integrity and balance of the town within the National Park. But what can be said of the economic or social sustainability of tourism in Banff and of the community itself? Is it possible to generate a consistent and healthy tourism industry and a sense of community when the population is in constant flux? And how does that affect the young adult tourism workers?

What Role Does Young Adult Workers' Agency Have in the Tourism Industry, in the Community of Banff, and for Their Future Work Experiences?

It is important to acknowledge that young adult tourism workers have different objectives with regard to their work and living experiences in Banff. Documenting what they want and get out of these early work experiences in Banff must include a discussion of their own agency and motivations. 
International Journal of Child, Youth and Family Studies (2021) 12(2): 65-87

Young adult tourism workers in Banff have been stigmatized by some permanent town residents as "transient" (Husdal, 2014). More accurately, they have found themselves with an ambiguous role, both "on the move" and "staying": simultaneously travellers and workers, guests and residents; in transit and at their destination, travelling through a place and dwelling in that place.

Some of these young adult workers had no expectation or intention that their tourism jobs would be lasting or permanent: they wanted, or were able, to work for only a season or two. This might be because they were students who worked in their off-semesters in 3- or 4-month blocks. Some were international workers on international exchange visas with finite work period permits (usually up to 2 years). Some were adventurers working to travel, rather than travelling to work, where work is their means to an end: to stop working and to move on. They are "tourist-migrant" (Uriely, 2001) workers working in the tourism industry because it allowed for the flexibility they were seeking. In this way, these young adults were controlling their own agency over their work and mobility.

The liminal space of the traveller is often set in opposition to the "real world": travel life is not the mundane world of everyday life and work, but stands in contrast to that life. When one is travelling, the rules and norms of the everyday have less force. Thus, young adults in this situation are often perceived as behaving in ways that are considered unruly, disruptive, or disrespectful: "here for a good time, not a long time". But it also means that they do not expect to be well paid or find permanent work with a prospect of advancement. Many of the young adult workers in the focus groups (Sessions $1 \& 2$, July 25, 2013) said that they came for the same reasons: partying, having fun, taking "breaks from the real world", "smoking weed", and meeting up with other young people from around the world with similar interests and at a similar stage of life. Chris (a pseudonym), an Australian working in the local hostel, captured this as he said: "I got friends back home settling down and having kids and buying homes and stuff, but I don't want that yet. I kind of just want to give it some time, and let things happen if they happen" (Interview L, August 25, 2016).

I have discussed how the "blurring" of lines between travellers and worker residents had negative effects on the young adults and also on the sustainability and well-being of the community. However, because their motivations are different, the impacts on young adult workers are different. Some former young adult tourism workers that I interviewed were bitter about their work experience in Banff, saying that they couldn't support themselves there and so had to leave. They focused on the hardships of living in overcrowded, expensive accommodations, working multiple jobs to make ends meet, and ultimately having to leave Banff in order to get "real work", by which they mean security, the ability to "make a living", and the ability to leave behind their former work mobility patterns and "put down roots". But some young adult workers who were formerly and presently engaged in tourism work clearly communicated that they had gained invaluable skills in negotiating and navigating the precarity of the work environment, having used 
International Journal of Child, Youth and Family Studies (2021) 12(2): 65-87

their own agency and the flexibility of the work to increase their resiliency and adaptability. These are the lasting consequences which may follow them into future work experiences.

\section{Conclusion}

Unlike some other research on the relationship of employment to the geographic mobility of workers (Halseth \& Ryser, 2017; Vodden \& Hall, 2016), my research does not focus on the reccurring journeys of a single worker into the site of employment (e.g., "fly-in/fly-out" camps). Rather, tourism workers journey to Banff for what is usually a short period of employment, leaving when the work ends. Also, my research is focused on a particular place and a single industry, not on multiple destinations or multiple professions. Thus, part of the story of these tourism workers must be connected to issues of the sustainability of that community in relation to tourism. The Banff community, with its high cost of living and its attempts to limit the population, is as much a contributor to the precarity of the young adult workers as is the tourism industry in which they work.

For some young tourism workers, mobility is their goal: they aim to use work as their means of travelling rather than travelling to work. For them, the economic and social marginality in the tourism industry is no deterrent. Instead, these young adults take advantage of the flexibility and temporariness of this work experience. They adapt to the work conditions and navigate them to their own benefit, learning instrumental skills, resilience, and resourcefulness along the way.

The abilities and the agency of the young workers - who are deemed "essential" to the tourism industry in Banff — seem in contrast to the undeniable precarity of the tourism industry and the unique situation of the community of Banff, which regards the workers as "disposable". This ambiguity is fundamental to the operation of the tourist economy in Banff. It shapes the very identity and nature of the community as much as it shapes the identity of the workers. Part of that identity exists in the tensions and ambiguities that are created through the double role of the young adult worker: on the one hand an "outsider" and traveller, and on the other a local "insider" working in tourism. A better understanding of these seeming contradictions between precarity and agency depicts them as a product of the unsustainability of the tourism industry and community, allowing a more complete picture of the early work and mobility experiences of young adult tourism workers. This is all the more important as, in a climate of economic change and restructuring, young adult workers are becoming central to the consideration of employment policy issues. 
International Journal of Child, Youth and Family Studies (2021) 12(2): 65-87

\section{References}

Banff Lake Louise Hotel Motel Association (BLLHMA). (2014). The Banff Lake Louise destination labour attraction and retention strategy.

Broverman, A. (2021). How much should you spend on rent? Greedyrates. https://www.greedyrates.ca/blog/how-much-to-spend-on-rent/

Campbell, C. E. (2011). Governing a kingdom: Parks Canada, 1911-2011. In C. E. Campbell (Ed.), A century of Parks Canada, 1911-2011 (pp. 1-20). University of Calgary Press.

Community Housing Strategy Committee. (2014). Town of Banff housing strategy. Town of Banff. https://banff.ca/DocumentCenter/View/2153/Town-of-Banff-Housing-Strategy

CTV News. (2018, October 1). Banff 'bursting at the seams': Ecologists urge cap on park visitors. https://www.ctvnews.ca/canada/banff-bursting-at-the-seams-ecologists-urge-cap-onpark-visitors-1.4116320

D'Aliesio, R. (2014, November 17). Clampdown on foreign workers puts Banff in a bind. Globe and Mail. http://www.theglobeandmail.com/news/national/banff-employers-scramble-to-findstaff-before-tourists-arrive/article21633097/

Deloitte LLP. (2014). The Town of Banff economic prosperity strategy. Town of Banff. https://banff.ca/DocumentCenter/View/2094/Economic-Prosperity-Strategy

Ellis, C. (2013, August 8). Banff's population set to exceed cap set by Parks Canada. Calgary Herald.

http://www.calgaryherald.com/news/alberta/Banff+population+exceed+Parks+Canada/87696 $\underline{\text { 29/story.html }}$

Ellis, C. (2019, October 2). Banff's rental vacancy rate inching up. Rocky Mountain Outlook. https://www.rmotoday.com/banff/banffs-rental-vacancy-rate-inching-up-1724489

Employment and Social Development Canada. (n.d.). Temporary foreign worker program. https://www.canada.ca/en/employment-social-development/services/foreign-workers.html

Enns, D. (2018). Briefing: 2017 municipal census. Town of Banff. http://banff.ca/DocumentCenter/View/5117

Family and Community Support Services. (2014). Banff community social assessment. Town of Banff. https://ab-banff2.civicplus.com/DocumentCenter/View/1752/Banff-Community-SocialAssessment-2012 2013?bidId= 
International Journal of Child, Youth and Family Studies (2021) 12(2): 65-87

Gerrits, A., Harrison, J., \& Pryor, R. (2019). The Banff community social assessment [Draft]. Town of Banff. https://banff.ca/DocumentCenter/View/6315/2018-Banff-Community-SocialAssessment

Halseth, G., \& Ryser, L. (2017). Towards a political economy of resource-dependent regions. Routledge.

Husdal, D. (2014, February 12). "Boarding house for transients" opposed. The Bow Valley Crag and Canyon. http://www.thecragandcanyon.ca/2014/02/12/boarding-house-for-transientsopposed

Immigration and Citizenship Canada. (n.d.). International Experience Canada: Who can apply. https://www.cic.gc.ca/english/work/iec/eligibility.asp

Langemann, E. G. (2011). Archaeology in the Rocky Mountain National Parks: Uncovering an 11,000-year-long story. In C. E. Campbell (Ed.), A century of Parks Canada, 1911-2011 (pp. 303-331). University of Calgary Press.

Lee, D., Hampton, M., \& Jeyacheya, J. (2015). The political economy of precarious work in the tourism industry in small island developing states. Review of International Political Economy, 22(1), 194-223. https://doi.org/10.1080/09692290.2014.887590

Macfarlane, B. (2020, March 18). Thousands laid off in Bow Valley as tourism screeches to a halt. CTV News. https://calgary.ctvnews.ca/thousands-laid-off-in-bow-valley-as-tourism$\underline{\text { screeches-to-a-halt-1.4858662 }}$

Meier, N. (2013). Town of Banff - Defining economic prosperity: September 2012-March 2013 [Final report]. Town of Banff. https://banff.ca/DocumentCenter/View/1260/DefiningEconomic-Prosperity-in-Banff

Mihalic, T. (2020). Conceptualising overtourism: A sustainability approach. Annals of Tourism Research, 84, 1-12. doi:10.1016/j.annals.2020.103025

Morgan, G. (2020, June 26). 'Great time for Alberta to take Banff back': Tourist towns seek locals as international visitors vanish. Financial Post.

https://financialpost.com/news/reopening-canada/great-time-for-alberta-to-take-banff-backtourist-towns-seek-locals-as-international-visitors-vanish

Munasinghe, M. (2007). Making development more sustainable: Sustainomics framework and practical applications. Munasinghe Institute for Development.

Pivotal Research. (2011). Banff municipal census 2011. Town of Banff. https://banff.ca/DocumentCenter/View/526/2011-Banff-Municipal-Census 
International Journal of Child, Youth and Family Studies (2021) 12(2): 65-87

Retail Council of Canada. (2021). Minimum wage by province. https://www.retailcouncil.org/resources/quick-facts/minimum-wage-by-province/

Sainsbury, B. (2021). Canada's best national parks. Lonely Planet. https://www.lonelyplanet.com/articles/best-national-parks-canada

Smith, A. (2018a, April 3-7). The land of fire and ice: Migrant workers and sustainability in the tourism industry in Iceland [Paper presentation]. 78th Annual Meeting of the Society for Applied Anthropology, Philadelphia, Pennsylvania.

Smith, A. (2018b, November 18-21). Young adult tourism workers: Mobility and community in Banff National Park, Canada [Paper presentation]. On the Move: Employment-Related Geographical Mobility in Canada \& Beyond - International Symposium, Memorial University, Signal Hill Campus, Battery Facility, St. John's, Newfoundland.

Standing, G. (2016). The precariat: The new dangerous class [Reprint]. Bloomsbury Academic.

Statista. (2020) Number of visitors to Banff National Park in Canada from 2011 to 2019. Accessed June 15, 2020 from https://www.statista.com/statistics/501614/visitors-to-banffnational-park/

Statistics Canada. (2013). Employment generated by tourism (x 1,000) [CANSIM Table 3870003]. doi:10.25318/3610023201-eng

Statistics Canada. (2015). Summary table: Full-Time and part-time employment by sex and age group. http://www.statcan.gc.ca/tables-tableaux/sum-som/101/cst01/labour12-eng.htm.

The Job Resource Centre. (2019a). Bow Valley labour market review: Spring 2019. https://static1.squarespace.com/static/5a285c22f14aa1c12b62ed30/t/5c8a9834eb39311ded8e7 30b/1552586808756/SPRING+2019+LMR.pdf

The Job Resource Centre. (2019b). Bow Valley labour market review: Fall 2019. https://static1.squarespace.com/static/5a285c22f14aa1c12b62ed30/t/5d8e88c43043100cd9bd7 503/1569622214863/FALL+2019+LMR.pdf

Tourism Industry Association Canada, \& Banff and Lake Louise Hospitality Association. (2014). Banff \& Lake Louise labour shortage study. https://tiacaitc.ca/ Library/TIAC Publications/Banff Lake Louise Labour Shortage Study FINAL Dec14.pdf

Town of Banff. (2021a). Indigenous peoples. https://banff.ca/1103/Indigenous-Peoples

Town of Banff. (2021b). Move to Banff. https://banff.ca/164/Move-to-Banff 
International Journal of Child, Youth and Family Studies (2021) 12(2): 65-87

Town of Banff Information. (2019). Banff's apartment vacancy rate grows to $1.1 \%$. https://www.banff.ca/CivicSend/ViewMessage/message/95933

United Nations World Tourism Organization (UNWTO). (n.d.). EU guidebook on sustainable tourism for development. https://www.unwto.org/EU-guidebook-on-sustainable-tourism-for$\underline{\text { development }}$

United Nations World Tourism Organization (UNWTO); Centre of Expertise Leisure, Tourism \& Hospitality; NHTV Breda University of Applied Sciences; and NHL Stenden University of Applied Sciences. (2018). 'Overtourism'? Understanding and managing urban tourism growth beyond perceptions [Executive summary]. doi:10.18111/9789284420070

Uriely, N. (2001) 'Travelling workers' and 'working tourists': Variations across the interaction between work and tourism. International Journal of Tourism Research, 3(1), 1-8. doi:10.1002/1522-1970(200101/02)3\%3A1<1\%3A\%3AAID-JTR241>3.0.CO\%3B2-M

Vodden, K., \& Hall, H. (2016). Long distance commuting in the mining and oil and gas sectors: Implications for rural regions. The Extractive Industries and Society, 3(3), 577-583. $\underline{\text { doi:10.1016/j.exis.2016.07.001 }}$

Wall, G. (2019). Perspectives on the environment and overtourism. In R. Dodds \& R. W. Butler (Eds.), Overtourism: Issues, realities and solutions (pp. 27-45). De Gruyter.

Wall, G. (2020). From carrying capacity to overtourism: A perspective article. Tourism Review, 75(1), 212-215. doi:10.1108/TR-08-2019-0356

Williams, A. (2012). Tourism, migration and human capital: Knowledge and skills at the intersection of flows. In W. C. Gartner \& C. Hsu (Eds.), The Routledge handbook of tourism research (pp.251-264). Routledge.

World Commission on Environment and Development). (1987). Our common future [The Brundtland report]. Oxford University Press. 